\title{
THE APPLICABILITY OF THE RIGHT TO A FAIR TRIAL IN CIVIL PROCEEDINGS: THE EXPERIENCE IN UKRAINE
}

\author{
Natalia Sakara \\ Sakaranatasha@gmail.com \\ https://orcid.org/0000-0001-8501-3756
}

Summary: 1. Introduction - 2. The Legal Nature of the Right to a Fair Trial - 3. The scope of the Applicability of the Right to a Fair Trial - 3.1. Legally Bound Subjects - 3.2. The dispute over the Right as the Measure of Applicability 3.3. The diversification of Judicial Procedures - 3.4. The civil nature of the Rights and Duties as the Protection Objects. 4. Conclusions.

To cite this note: $N$ Sakara 'The Applicability of the Right to a Fair Trial in Civil Proceedings: the Experience in Ukraine' 2021 1(9) Access to Justice in Eastern Europe 199-222. D0I: 10.33327/AJEE-18-4.1-n000053

To link to this note: https://doi.org/10.33327/AJEE-18-4.1-n000053

Submitted on 14 0ct 2020 / Revised 21 Dec 2021 / Revised 21 Febr 2021 / Approved 22 Feb 2021 / Published online: 01 Mar 2021 View data

Submit your article to Access to Justice in Eastern Europe http://ajee-journal.com/submissions

\section{ACKOWLEDGMENTS}

The author would like to express her endless gratitude to the reviewers and the English editors for their help.

\section{CONFLICT OF INTEREST}

The author has declared that no conflict of interest or competing interests exist, in particular, within her activities as a judge of the Supreme court. This study was solely a result of the author's academic research.

\section{CONTRIBUTOR}

The author is solely responsible for the reading and the approval of the final version and has agreed to be accountable for all aspects of this note.

Sakara Natalia is a PhD in Law, Associated Professor, Judge of Supreme Court. 


\title{
THE APPLICABILITY OF THE RIGHT TO A FAIR TRIAL IN CIVIL PROCEEDINGS: THE EXPERIENCE IN UKRAINE
}

\author{
Sakara Natalia \\ $\mathrm{PhD}$ (Law), Judge of the Supreme Court, Ukraine
}

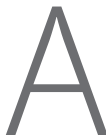

bstract In this note, the author attempts to prove that the right to a fair trial is essentially a substantive right; that is, a right that combines the manifestations of a fundamental right. At the same time, this right imposes some positive duties on the State to provide for it. It has national and supranational regulations, and at the same time reflects subjective law and axioms, as well as elements of procedural and substantive law. Attention is drawn to the fact that in Ukraine the legal nature of this right is implemented only partially, since neither legislation nor judicial practice recognize it as an independent object of protection.

Taking into account the provisions of Para 1, Art. 6 of the ECHRs and the case law of the ECtHR, the research proposes to define the scope of the applicability of the right to a fair trial proceeding from: (1) legally bound subjects, which may include not only courts within the judicial system of the country concerned on the basis of the law, but also other jurisdictional and quasi-judicial bodies; and (2) the procedures in which the guarantees of a fair trial must be observed. Depending on the existence or absence of a dispute over the rights in them the latter is divided into 'disputed', 'conditionally disputed' or 'indisputable'. It is proved that the requirements of Art. 6, Para 1 of the ECHR do not apply to them, but that they are mandatory under the first two procedures. An attempt to analyse the recent positions of the ECtHR on the possibility of including protection measures in the scope of the application is made. Also, the author determines which of those protection measures provided in national law falls within the scope of this regulation. Furthermore, the author draws attention to the fact that the rights and duties to protect a person who is invoked must be 'civil in nature' in order to be covered by the guarantees of a fair trial. On the basis of certain criteria the author identifies procedures in the national legal system within which the right to a fair trial must be guaranteed.

Keywords: a right to a fair trial, substantive law, scope of applicability of the fair trial right, court, established by law, judicial procedures, legal dispute, diversification of judicial procedures, 'civilistic' rights and duties.

\section{INTRODUCTION}

In 1950, during the regional institutionalization of human rights in Europe, the ECHR was adopted. Despite the fact that almost 70 years have elapsed, the interest in this international instrument grows year by year, primarily because it was with the adoption of the ECHR that fundamental human rights were recognized and codified not only at the constitutional level of individual countries but also at the international level. This has led to the imposition on ECHR member countries of a positive duty to ensure compliance with the European standards of human rights protection, the failure or improper enforcement of which also enables rights protection at the supranational level through the ECtHR. The ECtHR, in 
turn, may establish not only that fundamental rights have been violated on the basis of the outcome of individual complaints, but also that the country concerned should be brought to material responsibility by collecting just compensation in favour of the applicant, with the obligation to eliminate errors at the national level leading to this. Thus, fundamental human rights have received the highest degree of recognition and protection since the adoption of the ECHR, i.e. their fundamental nature was established ${ }^{1}$.

Among the rights enshrined in the ECHR which the member countries are obliged to guarantee, the right to a fair trial is one of the most important. Despite its fundamental nature, it is not always respected at the national level. The statistics for the period from 1959 to 2019 show that there was a violation of Art. 6, Para 1 of the ECHR in 11,543 cases. The greatest number of violations of the right to a fair trial were found in cases where the defendants were in: Turkey $(1,605)$, Italy $(1,501)$, the Russian Federation $(1,237)$, Ukraine $(1,038)$, Greece (693), Romania (651), France (565), etc. ${ }^{2}$ In 2019 there were 334 such cases: in the Russian Federation (86), Ukraine (58), the Republic of Moldova (27), Hungary (27), etc. $^{3}$ The description given, in our view, can be explained, inter alia, by: (1) the imperfect nature of this right, which presupposes its legislative regulation at the national level; (2) a certain states' autonomy in the introduction of restrictions which reflect the national specificity of a particular legal system; and (3) the use by the ECtHR of an autonomous and evolutionary rights interpretation that allows for derogation from an already formulated position. As a result, the right to a fair trial is understood as a dynamic system of guarantees.

All things considered, and due to the gradual expansion of the content of a fair trial right under this note, we believe it necessary to address the scope of this right since the correct determination of the latter is a condition for its observance, taking into account the legal nature of the right to a fair trial and the ECtHR practice. However, given that Ukraine has gradually undertaken judicial reform thoughout 2016 to 2020, which has directly affected the sphere of civil procedure, it is advisable to analyse some of its innovations.

\section{THE LEGAL NATURE OF THE RIGHT TO A FAIR TRIAL}

There are many classifications of human rights according to different criteria in the literature but it is generally accepted that all rights are differentiated according to the content of the needs for which they provide. In some cases, the right to a fair trial falls under the political or civil rights cluster or under a separate set of procedural rights (rights-guarantees). Although, in most cases, it has no place in this classification.

However, as for determining the legal nature of the right to a fair trial, it should be based primarily on the fact that it is a treaty right, and the approach suggested by the ECtHR should be taken into account. For the latter, all the rights enshrined in the ECHR are divided into two groups: substantive and procedural. ${ }^{4}$ In science, this distribution is based on the criterion of entitlement, and exists in parallel with the classification of human rights according to the content of needs. Traditionally, substantive rights are contrasted with procedural rights, ${ }^{5}$

1 NY Sakara, 'Impact of the human rights fundamentalization on the development of the fair trial right' Rule of law issues (2017) 13851.

2 ECtHR, 'Violations by Article and by State 1959-2019'<https://www.echr.coe.int/Documents/Stats_ violation_1959_2019_ENG.pdf $>$ accessed 6 February 2021.

3 ibid.

$4 \quad$ G Lautenbach, The Concept of the Rule of Law and the European Court of Human Rights (OUP 2013) 174;

5 WA Thurman, 'The Role of Substantive Law and Procedure in the Legal Process' (1932) XLV (4)

Harward Law Review 639, 643-644. 
although substantive and procedural law are recognized as being interrelated and mutually influential. ${ }^{6}$ However, we believe that this approach requires some clarification.

Today there is no single point of view of what exactly is meant by the category 'substantive'. As already mentioned, in most cases, it is equated with 'material'. That is, substantive rights are used as a synonym for material rights. ${ }^{7}$ However, different interpretations can be found. Thus, individual researchers emphasize the self-sufficiency of the right to a fair trial as evidenced by the fact that the ECtHR recognizes its violations, regardless of whether other substantive rights have been violated under the ECHR. It follows from the abovementioned that the substance of a right is linked to its autonomous status, that is its independence from other rights and the possibility of its protection. Other scientists also reveal the category substantive through the integrative character and the possibility of combining mutually exclusive properties, ${ }^{8}$ the interaction of international and national law on a parity basis, ${ }^{9}$ and the means of ensuring public order through private law methods. ${ }^{10}$ In turn, the European Commission for Democracy through Law (Venice Commission) also uses the category substantive with several meanings. First, it emphasizes the fundamental nature of the rule of law that permeates all articles of the ECHR. Second, they are characterized by concepts whose content includes, among other things, namely: 'respect for fundamental rights, which rank alongside official (the rule of law) and European Union law-specific concepts (the fair application of the law, effective enjoyment of rights under European Union law, respect for the laws of expectation and even the fight against corruption) or axiomatic notions in other words. Third, there is a substantive interpretation of the term Rechtsstaat both in the Constitutional law doctrine of Germany and in the practice of the Constitutional Court; that is, it is autonomous. Fourth, this category is used as a synonym for the category 'material.' ${ }^{11}$

An analysis of the cited points of view makes it possible to conclude that the substantive category is most often used to emphasize the peculiarities of a legal phenomenon through the prism of its essence, if the latter cannot be unequivocally characterized using concepts without forming an antinomy. The latter is due to the existence of a concepts dichotomy that cannot be reconciled. It is appropriate to define the right to a fair trial as a substantive right.

The substance of the right to a fair trial is reflected in the following. First, this right refers to fundamental human rights, ${ }^{12}$ that is, rights that belong to human beings by birth. They are derived from and linked to our nature and in this sense, this right is an inalienable part of human life. At the same time, this right is not absolute, i.e. the position of the ECtHR allows its legislation to be regulated at a national level and for the State to retain a certain autonomy in introducing any restrictions consequently, to reflect the national specificities of

$6 \quad$ MK Yukov, 'Civil Procedural Law. Issues of development and protection of citizens' rights' (RE Gukasian ed, Kaliningradskiy Gos. Universitet 1977) 66-75.

$7 \quad$ JR Temirbekov, 'Some features of understanding the rule of law in US constitutional theory' (2015) 1 (66) Law and State 53-54.

8 OM Sviridenko, 'Substantive legal relations as an integral part of the insolvency (bankruptcy) concept' (2010) 11 Modern law 76-77.

9 SA Savchenko, 'Interaction Process of norms and principles of international and national law' (2010) 3 Gazette of the Moscow University of the Ministry of Internal Affairs of Russia 154.

10 TV Sahnova, 'Right to Judicial Protection as a Substantive Procedural Law: The Effect of Globalization' (2014)3 The Bulletin of Civil Procedure 11-25.

11 European Commission For Democracy through Law (Venice Commission), Report on the Rule of Law. Venice, 25-26 March 2011 <http://www.venice.coe.int/webforms/documents/default. aspx?pdffile=CDL-AD(2011)003rev-rus $>$ accessed 6 February 2021.

12 NY Sakara, 'Impact of the human rights fundamentalization on the development of the fair trial right' (2017) 138 Problemy Zakonnosti 43-54. 
a particular legal system. In other words, this right is not entirely a negative right ${ }^{13}$ like all fundamental rights, because it imposes positive obligations on the State to create conditions for its realization, i.e. there is a symbiosis of positive and negative rights.

Second, the right to a fair trial emerged as a national right, that is, as a right recognized and guaranteed by individual countries. However, further international and regional institutionalization has resulted in it becoming a supranational European standard of human rights with obligations for its implementation, i.e. an upward and downward internationalization. This, in turn, resulted in the creation of a universal standard of human rights firmly established in the national legal order at both the constitutional and sectoral levels. At the same time, the provisions that are included in its content are relatively certain, since the ECtHR applies an autonomous and evolutionary interpretation of the ECHR in its activities. Despite the principle of subsidiarity, it is the ECtHR that determines the requirements, which must be respected by national judicial authorities when considering and deciding cases, i.e. the court derivatively formulates the content of procedural rights, regardless of their recognition in national legislation, or otherwise, in relation to the right to a fair trial.

Third, while the right to a fair trial is articulated as a subjective right, it should also be identified as an axiom of civil procedural law that is self-evident in truth and should be perceived as having a clear legal value. In its basis lie such truths as: 'Where there is a right, there is a remedy', 'hear the other side', 'the right to be listened and the right to be heard, 'justice must not only be done, but it must be seen to be done', 'the judge's operation, which does not fall within his competence, is useless', and 'the judge must be impartial. These maxims have undergone modern processing, have been merged into a whole and reproduced in the corresponding legal construction.

Fourth, a fair trial right is clearly a procedural right. It provides that everyone has the opportunity to initiate legal proceedings in respect of his or her civil rights and freedoms, to obtain effective judicial protection, and the state is obliged to create the appropriate conditions for its realization. All substantive human rights are recognized as fundamental objects that can be protected in their own right by the international, civilized community. However, as has already been noted, this right is of a specific nature because it combines elements of both positive and negative order. In addition, the individual components of this right (for example, the right to have the case examined and the execution of the decision within a reasonable time) are now recognized in the national legal order as independent objects of judicial protection, which allows for a mention of its materialization which is an attribution of substantive rights under certain conditions.

It follows from the above that the right to a fair trial should be defined as a substantive right, thus emphasizing its essence as a combination of the manifestations of fundamental rights. At the same time it imposes positive obligations on the State to ensure it. It is characterized by national and supranational determination, including the involvement of the ECtHR in shaping the content of procedural rights associated with it, regardless of their recognition at the national level, subjective law and axioms, as well as procedural and substantive law.

It should be noted that the substantive nature of the right to a fair trial is now partly implemented in national legislation and law enforcement practice in Ukraine. So, on the one hand, at the constitutional (Constitution of Ukraine, Arts. 55, 124, 126, 129) and sectoral levels (Law of Ukraine 'On the Judicial System and the Status of Judges', Arts. 2, 4, 7-15, 17, 18 , etc.), almost all the components of this right are enshrined and guaranteed accordingly. According to Art. 17 of the Law of Ukraine 'On the Execution of Decisions and the Application

13 OB Prokopenko, The fair trial right: conceptual analysis and implementation practice (Publishing House FINN 2011) 63. 
of the Practice of the ECtHR', the courts must apply the ECtHR case law as a source of law. However, the above-mentioned right does not yet enjoy the status of being an independent subject of judicial protection and consequently cannot be defended at the national level by means of an effective legal remedy, as has been repeatedly noted by the ECtHR with regard to Ukraine. Thus, the lodging of a complaint before a higher court about the inactivity of a lower court is not considered to be sufficiently effective to expedite proceedings, since, firstly, the instructions of the higher courts are non-binding recommendations only, ${ }^{14}$ and secondly, the initiation of disciplinary proceedings against the judge, which may result from a separate decision and be from a higher court informing the qualification commission of delays in the proceedings, is subject to the discretion of the relevant authorities and is not directly accessible to those concerned. ${ }^{15}$ In addition, since Ukrainian legislation does not provide for criminal liability for delays in the consideration of a case, the criminal proceedings initiation against a judge and the requirement to compensate for damage caused by a judge, in the course of a criminal case, may not be considered an effective remedy. ${ }^{16}$

Art. 1176, para. 5 of the CPC of Ukraine establishes that harm caused to a physical or legal person as a result of an unlawful decision by a court in a civil case is fully compensated by the State if the actions of a judge (judges), which influenced the resolution of the unlawful decision, contained the elements of a crime according to the conviction of the court that became enforceable. It follows from the above that, as a first condition, the State will make reparation for the damage caused, only if the latter is the consequence of an unlawful judgement in a civil case, that is, a court decision adopted in violation of procedural and substantive law. According to Art. 410, para. 2 of the CPC, a just and lawful decision cannot be overturned for purely formal reasons alone. This means that if non-compliance with the requirements of Art. 6, para. 1 of ECHR has not resulted in an unlawful court decision, the damage caused by the violation of a fair trial right is not subject to compensation. In other words, there is no basis for applying the compensation mechanism. Furthermore, as a second condition, the State will make reparation for the damage caused only if the legality of the court decision is established, if the judge is convicted, and the causal link between the crime and the violated right is recognized. However, the need to establish the guilt of judges by a court sentence that has become enforceable means that material damage is not compensated in practice. In turn, Art. 1176, Para 6 of the CPC establishes that if the damage caused to a physical or legal person is a result ofan unlawful action, an inaction or an unlawful decision of the body of inquiry, then the preliminary (pre-trial) investigative body, the procurator's office or the court shall be reimbursed in accordance with the general principles. With this, however, the current Ukrainian legislation does not answer the question of what is meant by such actions, inactions or decisions. Moreover, according to Art. 1166, 1167 of the CPC, which provide for general grounds of liability for damaged property and moral damage, such damage must be compensated by the person who caused the damage, that is, by the judge. However, it is impermissible in the context of the principle of the judges' independence and their subordination only to the law, as well as in the determination of the guilt of such a person, that is, a judge. However, both the ECtHR and the Supreme Court have repeatedly stressed in their rulings that appeals against the actions of judges (courts) concerning the examination and resolution of cases, as well as appeals against court decisions, outside the procedure prescribed by procedural law are not admissible. That is, there is no higher court. Courts and judges may not be defendants in cases of appeal against their acts or inaction in other court cases or against their decisions taken as a result of such cases, as well as against

14 Karimov v Ukraine App no 69435/01, para 74 (ECtHR, 31 January 2008).

15 Efimenko v Ukraine App no 55870/00, para 64 (ECtHR, 18 July 2006).

16 Loshenko $v$ Ukraine App no 11470/04, para 30 (ECtHR, 11 December 2008). 
the obligations of courts and judges to perform certain procedural actions. ${ }^{17}$ In addition, para. 7, Art. 1176 of the CPC explicitly establishes that the procedure for compensation for damage caused by unlawful decisions, acts or inaction of the body conducting the search activity - the pre-trial investigation body, prosecutor's office or court - is established by law. Since such a law has not been adopted in the territory of Ukraine yet, it is impossible to rectify the damage caused by the violation of the right to a trial within a reasonable time.

As for the right to the execution of a court decision without undue delay, which is a constituent part of a fair trial right, in Ukraine an attempt to introduce a compensatory mechanism for its protection was made through the adoption of the Law of Ukraine 'On the State guarantees regarding the implementation of judicial decisions' no. 4901-VI of 05 June 2012. The law concerns the late execution of court decisions against State authorities and enterprises. However, the mechanism introduced was recognized by neither the Committee of Ministers of the Council of Europe nor the ECHR as an effective remedy, as indicated in the Burmich and Others v. Ukraine case. ${ }^{18}$

\section{THE SCOPE OF THE APPLICABILITY OF THE RIGHT TO A FAIR TRIAL}

According to Art. 6, Para 1 of ECHR, the right to a fair trial must be ensured by the court in resolving the dispute over rights and duties. It follows from this rule that the extent of its applicability is not universal despite the fundamental nature of this right. That is, it must be determined at the national level, allowing for the specificity of the respective legal system and national legal traditions. However, in view of the composition of the relevant rule, the criteria to be taken into account in determining its limits are: (1) legally bound entities which, according to Art. 6 para. 1 of the ECHR, are obliged to ensure respect for the abovementioned right and the procedures which it guarantees. By the latter, it is useful to mean a set of formalized policies aimed at achieving an expected and determined legal result, which have their own rules, a legislatively defined beginning and ending, and their own object and subject. ${ }^{19}$ The list of such procedures is determined according to their ability to resolving how a 'dispute over rights and duties' has a 'civil character'.

\subsection{Legally Bound Subjects}

It follows from the content of Art. 6, para. 1 of the ECHR that the courts are legally bound subjects primarily. Thus, according to Art. 125 of the Constitution of Ukraine, Paras 1-3 of Art. 17 of the Law of Ukraine 'On the judicial system and the status of judges' the judicial system is based on the principles of territoriality, specialization and instance. The Supreme Court is the highest court in the judicial system. The judicial system consists of: local courts, courts of appeal, and the Supreme Court. In accordance with the principle of specialization, there are general, administrative courts, the High Court of Intellectual Property and the Supreme Anti-corruption Court.

In contrast to the current legislation of Ukraine, the ECtHR applies a slightly broader interpretation of the category 'tribunal', indicating that it does not always have to be a 'classical court' integrated into the 'state court' system. Such an authority could be established to deal

17 Case no. 757/43355/16-ц (Resolution of the Supreme Court, 21 November 2018).

18 Burmych and Others $v$ Ukraine App no 46852/13 (ECtHR, 12 October 2017).

19 TV Sakhnova, 'Procedure of the Civilistic Process: Future Methodology' (2012) 1 Bulletin of the Civil Process 13-14. 
with individual issues and regulated accordingly outside the ordinary judicial system. ${ }^{20}$ However, their employees need not be lawyers or professional judges. ${ }^{21}$ Moreover, the fact that it performs various functions (administrative, regulatory, advisory and disciplinary) does not indicate that it cannot be considered as a court in itsel $\mathrm{f}^{22}$ provided that, in essence, it performs a judicial function, that is, the function of adjudicating matters within its competence on the basis of the rule of law within the framework of a duly conducted order. ${ }^{23}$ This requires that such an authority should be vested with the legal authority to deal with all matters of both fact and law relevant to the case. ${ }^{24}$ This means either granting it 'sufficient jurisdiction' or entrusting it with the function of 'judicial supervision. ${ }^{25}$ The scope of factfinding may be limited, as such a body should evaluate the previous review rather than take actual decisions. The role of Art. 6, Para 1 of the ECHR is not limited to ensuring access to a court with the jurisdiction to substitute the decisions of administrative authorities with its own decisions. In this context, emphasis is placed on the respect to be provided by the decision of the administrative authorities proceeding from their 'feasibility' as they either relate to specific branches of the law (e.g. planning, environmental protection, gambling regulation, etc.) ${ }^{26}$ or are adopted in cases in which the jurisdiction of the judicial review body is limited by the technical nature of the subject matter of the dispute. ${ }^{27}$ In assessing whether the review has been carried out at a sufficient level, the ECtHR takes into account the powers granted to this 'court' or 'tribunal', as well as such circumstances as: the decision to be disputed, that is, whether it concerns a certain branch that requires special knowledge, or to what extent it allows discretion; the method used in its adoption, including the procedural guarantees that exist during the case consideration by the administrative authority; and the content of the dispute, including the means of appeal, both desirable and existing. ${ }^{28}$

In addition to the requirement on the scope of its powers, the ECtHR also considers that the decision of the body that can be regarded as a court should be of a general binding character and not of a recommendatory nature ${ }^{29}$ and it cannot be set aside by non-judicial bodies. ${ }^{30}$ As an example, the ECtHR regarded the Local Real Property Transactions Authority as a court, ${ }^{31}$ the authority which decides on compensation for damage caused by the crime (the Criminal Damage Compensation Board), ${ }^{32}$ the Arbitration Tribunal ${ }^{33}$ etc. At the same time, the status of this 'court' was not extended to the body which, although being integrated into the classical judicial system, had discretionary powers limited by the decision of the executive branch. ${ }^{34}$ In Ukraine, apart from the courts of the judicial system there is the International Commercial Arbitration Court at the Chamber of Commerce and the Industry

20 Rolf Gustafson $v$ Sweden App no 23196/94 (ECtHR, 01 July 1997) para 45, Reports 1997-IV.

21 Ettl and Others $v$ Austria App no 9273/81 (ECtHR, 23 April 1987) para 36-41, Series A no 117.

22 Hv Belgium App no 8950/80 (ECtHR, 30 November 1987) para 50, Series A no. 127-B.

23 Sramek v Austria App no 8790/79 (ECtHR, 22 October 1984) para 36, Series A no. 84.

24 Terra Woningen BV v the Netherlands App no 20641/92 1(ECtHR, 7 December 1996) para 52, Reports 1996-VI.

25 Tsanova-Gecheva v Bulgaria App no 43800/12, para 97 (ECtHR, 15 September 2015).

26 Sigma Radio Television LTD v Cyprus Apps no 32181/04, 35122/05, para153 (ECtHR, 21 July 2011).

27 Al-Dulimi and Montana Management Inc $v$ Switzerland [GC] App no 5809/08 (ECtHR 2016) para 130.

28 Sa Patronale Hypothécaire c Belgique App no 14139/09, para 38 (ECtHR, 17 Juillet 2018).

29 Benthem $v$ Netherlands App no 8848/80 (ECtHR, 23 October 1985) para 40, Series A no 97.

$30 \quad$ Van De Hurk $v$ Netherlands App no 16034/90 (ECtHR 19 April 1994) para 45 Series A no 288.

31 Sramek $v$ Austria App no 8790/79 (ECtHR, 22 October 1984) para 36 Series A no 84.

32 Rolf Gustafson v. Sweden App no 23196/94 (ECtHR 01 July 1997) para 48 Reports 1997-IV.

33 Lithgow and Others $v$ The United Kingdom App nos 9006/80, 9262/81, 9263/81, 9265/81, 9266/81, 9313/81, 9405/81 (ECtHR, 08 July 1986) para 201 Series A no 102.

34 Van De Hurk v Netherlands App no 16034/90 (ECtHR, 19 April 1994) para 54 Series A no 288. 
of Ukraine recognized by the ECtHR as a 'court, in the law,' ${ }^{35}$ the High Council of Justice, the Parliamentary Committee and the plenary meeting of Parliament, ${ }^{36}$ although the Supreme Council of Justice now replaces the Supreme Council of Yustitsia ${ }^{37}$.

For some cases, it should be noted that the observance of certain elements of the right to a fair trial is checked by the ECHR, that is, the requirements of Art. 6, Para 1 of the ECHR apply to constitutional proceedings. Thus, in the decision in the case of Poliakh and others $v$. Ukraine, the ECtHR verified the observance of the right to a trial within a reasonable time, taking into account the time frame for the decision on the constitutionality of the Law of Ukraine 'On Lustration' no. 1682-VII of 16 September 2014 before the Constitutional Court of Ukraine. An understanding of the ECtHR indicates that such proceedings form part of the ordinary judicial procedure, since without resolving this issue, administrative courts could not consider the merits of the applicants' cases. $^{38}$

Under Art. 17 of the CPC, civil rights and interests may be protected by the President of Ukraine, State authorities, the authorities of the Autonomous Republic of Crimea or local self-government authorities. The administrative form of protection is reproduced in the jurisdictional activities of the above-mentioned authorities, ${ }^{39}$ which is inherently subsidiary, since it can only occur in cases expressly provided by law, without depriving a person of the right to judicial protection. As an example, under Art. 19 of the Family Code of Ukraine, a person has the right to previous recourse to the guardianship agency for the protection of his or her family rights and interests. The decision of the guardianship agency is binding if within 10 days of its issuance the person concerned has not applied to the courts for the protection of rights or interests, except in cases provided for in Art. 170, Para 2, of the Code. An application for protection from a guardianship agency does not deprive a person of the right to apply to a court.

It follows from the above that if at the national level civil rights and interests can be protected administratively by the authority that performs quasi-judicial functions, provided that it satisfies other requirements for the 'court' formulated in the ECtHR practice, it can be defined as a legally binding authority. That is, it is advisable for the ECtHR, when considering and deciding a case, to adhere to the guarantees laid down in Art. 6, Para 1 of the ECHR. However, in most instances, for such authorities these requirements are optional rather than mandatory and may therefore be applied in a limited, selective manner, ${ }^{40}$ since the administrative form cannot claim autonomy in civil relations ${ }^{41}$ and is the exception rather than the general rule. In addition, under Art. 55, Para 2 of the Constitution of Ukraine everyone is guaranteed the right to appeal to the courts against decisions, actions or inactions of State authorities, local self-government authorities, officials and employees. Thus, after the use of an administrative form of protection, a person always has the right to go to court.

In addition to judicial and administrative forms of protection, current Ukrainian legislation provides for an alternative form of protection. As an example, in accordance with Art. 4, Para 4 of the CPC, Art. 1, Para 2 of the Law of Ukraine 'On Arbitration Tribunals', any dispute

$35 \quad$ Regent Company v Ukraine App no 773/03 (ECtHR, 03 April 2008) para 54.

36 Oleksandr Volkov v Ukraine App no 21722/11 (ECtHR 2013) para 90.

37 Editor's note. See more in S Prylutskyi, O Strieltsova 'The Ukrainian Judiciary under 21st-Century Challenges' (2020) 2/3(7) Access to Justice in Eastern Europe 78-99.

38 Polyakh and Others $v$ Ukraine App no 58812/15 and 4 others (ECtHR 17 October 2019) para 186-192.

39 VV Komarov et al, Civic Process Course: Textbook [Kurs tsyvilnoho protsesu: pidruchnyk] (Law 2011$) 17$.

40 TA Tsuvina, 'Peculiarities of the calculation of the reasonable period of civil proceedings in the context of the jurisprudence of the European Court of Human Rights' (2015) 130 Problems of Legality 98.

41 TV Sakhnova, 'Civic Process Course: Theoretical Beginnings and Basic Institutions' (Wolters Kluwer 2008) 14. 
arising from civil and economic legal relations may be submitted to arbitration by agreement between the parties, except in the cases provided for by law. An arbitration tribunal is a nonState independent body established by agreement or by decision of the natural and/or legal persons concerned in accordance with the procedure established by this Law for the settlement of disputes, arising from civil and economic legal relations (Art. 2, Para 2 of the Law of Ukraine 'On Arbitration Tribunals'). International commercial arbitration is a variant of an arbitration tribunal. According to Art. 1, Para 2 of the Law of Ukraine 'On International Commercial Arbitration', the International Commercial Arbitration can review, by agreement of the parties: (1) disputes from contractual and other civil law relations arising in the conduct of international trade and other types of international economic relations if the place of business of at least one of the parties is abroad; and (2) disputes between enterprises with foreign investments and international associations and organizations established in the territory of Ukraine among themselves, disputes between their participants, and disputes between these enterprises with other subjects of Ukrainian law.

In its decisions, the ECtHR has taken a separate position to extend the requirements of Art. 6, Para 1 of the ECHR to the arbitration activity. Thus, the ECtHR distinguishes between statutory arbitration, which must respect the guarantees of the right to a fair trial and voluntary arbitration, which must generally adhere to the requirements mentioned by the parties, although, usually, there is no violation of the ECHR if the arbitral tribunal is convened on a voluntary basis and both parties have the same opportunity to influence the composition of the arbitration tribunal. ${ }^{42}$ In the latter case, by choosing this type of arbitration the parties relinquish some rights, expressly or implicitly, provided for in Art. 6 , Para 1 of the ECHR. The main consideration is that the refusal is voluntary, ${ }^{43}$ legal and unambiguous. In the case of procedural rights, an effective waiver should also comply with minimum guarantees in accordance with its meaning and should focus only on individual rights. However, a waiver does not mean that national courts should not have some control over the conduct of arbitration hearings leading to binding awards, nor does it mean that they are not responsible for such oversights. However, States have considerable discretion in regulating the reasons why an award should be set aside. ${ }^{44}$

The literature suggests that, given the importance of guarantees of a fair trial for the constitutional order of European countries, the latter should be fully applied by arbitration tribunals in the public interest. ${ }^{45}$ However, we believe that as voluntary arbitration is a variant of alternative dispute resolution, its 'formalization' will lead to a distortion of its substance and a decrease in quantitative and qualitative efficiency. Nevertheless, the State should be able to monitor the activities of such authorities through the State courts at the request of one of the parties, although such control should be limited to the mere verification of the voluntariness of the arbitration agreement, the result is that the individual waives his or her right of access to the court and complies with the basic provisions of the agreement between the parties on the procedure for the settlement of the dispute. However, compliance with all the requirements set out in Art. 6, Para 1 of the ECHR by the arbitration tribunals (arbitration) depends, first and foremost, on the existence of prior agreement between the parties to that effect, as set out in the arbitration agreement. At the same time, in the event of non-compliance, it follows that the State is not responsible for this, as it cannot influence the activities of such legal persons in any way. 
It should be noted that the scope of the applicability of the right to a fair trial is not purely limited to the jurisdictional activities of 'courts'. The ECtHR formulated the concept of 'the right to a court', one aspect of which is the right of access, which would be illusory if the legal system of a Contracting State allowed a binding final judgement not to be enforced to the detriment of one of the parties. Consequently, for the purposes of Art. 6, Para 1 of the ECHR, the execution of a decision taken by any court should be considered as an integral part of the judicial proceedings. ${ }^{46}$ Effective access to court includes the right to enforcement without undue delay, ${ }^{47}$ and is adopted by both national and foreign courts. ${ }^{48}$ Thus, State executive service authorities and private actors which, in accordance with the Law of Ukraine 'On authorities and persons enforcing court decisions and decisions of other bodies', enforce judicial decisions and decisions of other authorities in its activity and have to respect both reasonable time limits (that is, to avoid undue delay) and other guarantees that are the elements of the a trial right. ${ }^{49}$ The State is responsible for the effectiveness of the enforcement system. ${ }^{50}$

\subsection{Dispute over a right as a criterion of applicability}

In disclosing the meaning of the concept of 'dispute over a right', the ECHR proceeds from the fact that this category should not be interpreted too technically. That is, it should be dealt with on its substance, and not in the formal sense. The use of the French word contestation indicates that there is a disagreement ${ }^{51}$ between two opposing parties, which can be made up of two individuals, as well as one individual and the State. ${ }^{52}$ Such differences cannot be resolved through a non-conflict unilateral procedure available in the absence of a dispute about the right..$^{53}$ Inter alia, the existence of the latter may be evidenced by differing views expressed by the parties on the same issue..$^{54}$ At the same time, in ascertaining its reality, it is necessary to 'look beyond the limits of appearances and language', which is used in formulating a rule of law (i.e. to depart from its literal interpretation) and to focus on the real situation depending on the circumstances of each particular case. ${ }^{55}$

It follows that in order for a dispute over a right to arise, there must always be two opposing parties who, by their actions (or, indeed, inaction), demonstrate the existence of a difference between them over the disputed matter. If the latter is implicit or non-existent, the law should expressly caution against recourse to the courts to assert their rights. This will make it possible to overcome the 'actual' absence of a legal dispute, since we believe that the latter should be presumed because of the impossibility of exercising subjective rights.

The ECtHR has also formulated a number of requirements for a 'dispute over a right'. The first requirement is that the dispute must be genuine and serious ${ }^{56}$ or, in other words, claims to the court must be motivated, unless otherwise provided for, to avoid giving the impression

\footnotetext{
$46 \quad$ Hornsby v Greece App no 18357/91 (ECtHR,19 March 1997) para 40, Reports 1997-II.

47 Immobiliare Saffi v Italy [GC] App no 22774/93 para 66, ECHR 1999-V.

48 Saccoccia $v$ Austria App no 69917/01 (ECtHR, 18 December 2008) para 62.

49 V Turkanova, 'Open Enforcement: New Approach of Ukraine in Access to Justice' (2019) 2 Access to Justice in Eastern Europe.

$50 \quad$ Nosal $v$ Ukraine App no 18378/03 (ECtHR, 29 November 2005) para 40.

51 Le Compte, Van Leuven and De Meyere v Belgium App nos 6878/75; 7238/75 (ECtHR, 23 June 1981) para 45, Series A no 43.

52 Ringeisen v Austria App no 2614/65 (ECtHR, 16 July 1971) para 94, Series A no 13.

53 Alaverdyan v Armenia (dec) App no 4523/04 (ECtHR, 24 August 2010) para 35.

54 Procola $v$ Luxembourg App no 14570/89 (ECtHR, 28 September 1995) para 37, Series A no 326.

55 Van Droogenbroeck v Belgium App no 7906/77 (ECtHR, 24 June 1982) para 38, Series A no 50.

56 Sporrong and Lönnroth $v$ Sweden App nos 7157/75, 7152/75 (ECtHR, 23 September 1982) para 81, Series A no 52.
} 
that they are biased and unreasonable. ${ }^{57}$ For example, the ECtHR considers that where it is contested that HIV-positive prisoners are held together with other prisoners, ${ }^{58}$ or that films are not shown in prisons ${ }^{59}$, then these would require non-compliance with this requirement, and consequently would be excluded from the scope of Art. 6, Para 1 of the ECHR cases as these, in no way, violate the rights of persons and do not cause harm and do not create grounds for awarding compensation accordingly. Among other things this means that the person applying to the court must have a legal interest i.e. that person must apply for a protection of rights, freedoms and interests. ${ }^{60}$

Second, the dispute may relate not only to the existence of the subjective right, but also to the scope, sphere or mode of its realization. ${ }^{61}$ However, if the emergence of a subjective right depends on the commission of certain acts or the occurrence of circumstances provided for by law, the dispute may not arise until respective legal facts have taken place. ${ }^{62}$ Issues of both fact and law can be contentious, ${ }^{63}$ including the legal interpretation of a rule of law. ${ }^{64}$ However, in cases concerning the right to pursue certain activities, the assessment of the candidate's qualities, experience, the duration of the performance of a certain job, diploma and qualification carried out by the body authorized to decide issues on 'admission to the profession' cannot be contested since the latter is more like a 'school or university examination and it is very far from the judicial function. ${ }^{65}$

Third, the review outcome must be decisive for the disputed right or duty; a mere minor link or a remote effect is not sufficient for the application of Art. 6, Para 1 of the ECHR. ${ }^{66}$ However, this cannot be equated only to the consequences of the proprietary character ${ }^{67}$ For example, the ECtHR recognized that legal proceedings challenging the lawfulness of an extension of a licence to operate a power plant are not subject to this rule, since the link between the decision to extend and the right to protection of life, the physical integrity and property was 'too minor and too remote' and the complainants could not prove that they were directly at risk, which would have been not only serious but also specific and unavoidable. ${ }^{68}$ On the other hand, the ECtHR has approved the application of Art. 6, Para 1 of the ECHR, and the complainants' settlement, in the case of an appeal against the construction of a dam, as it could have caused flooding. ${ }^{69}$ This criterion seems to suggest that the decision of the court should determine and/ or affect the rights and obligations of the parties realistically (causation having been established), not possibly.

\footnotetext{
57 Rolf Gustafson v Sweden App no 23196/94 (ECtHR, 01 July 1997) para 39, Reports 1997-IV.

58 Skorobogatykh $v$ Russia (dec) App no 37966/02 (ECtHR, 8 June 2006).

59 Artyomov v Russia App no 14146/02 (ECtHR, 27 May 2010) para 198.

60 Ambruosi v Italy (dec) App no 31227/96 (ECtHR, 3 February 2000).

61 Zander $v$ Sweden App no 14282/88 (ECtHR, 25 November 1993) para 22, Series A no 279-B.

62 Gavrielides $v$ Cyprus App no 15940/02 (ECtHR, 1 September 2006) para 38.

63 Albert and Le Compte v Belgium App no 7299/75; 7496/76 (1 September 2006, 10 February 1983) para 27, 29, Series A no 58; Benthem $v$ the Netherlands App no 8848/80 (ECtHR, 23 October 1985) para 32, Series A no 97.

64 Van Marle and Others $v$ the Netherlands App nos 8543/79; 8674/79; 8675/79; 8685/79 (ECtHR, 26 June 1986) para 36, Series A no101.

65 Van Marle and Others $v$ the Netherlands (n 66); San Juan v France (dec) App no 43956/98 ECHR 2002-III.

66 Fayed $v$ the United Kingdom App no 17101/90 (ECtHR, 21 September 1994) para 56, Series A no 294-B.

67 Kurzac v Poland (dec) App no 31382/96 ECHR 2000-VI; Kuśmierek v Poland App no 10675/02 (ECtHR, September 2004) para 49, 21; Pieniążek v Poland, App no 62179/00 (ECtHR, 28 December 2004) para 20.

68 Balmer-Schafroth and Others $v$ Switzerland App no 22110/93 (ECtHR, 26 August 1997) para 40, Reports 1997-IV; Balmer-Schafroth and Others $v$ Switzerland (dec) App no 50495/99 (ECtHR, 13 September 2001); Athanassoglou and Others $v$ Switzerland [GC] App no 27644/95 para 46-55, ECHR 2000-IV. Gorraiz Lizarraga and Others $v$ Spain App no 62543/00 para 46, ECHR 2004-III
} 
Fourth, the subjective right in a dispute should be recognized in law, at least where there are controversial grounds, ${ }^{70}$ i.e. neither Art. 6, Para 1 of the ECHR nor the ECtHR aims to create new subjective rights ${ }^{71}$ or attribute new, uncharacteristic content to existing ones. ${ }^{72}$ Legislative provisions and its interpretation by national courts should always remain determinative. ${ }^{73}$ However, the discretionary power of the courts to decide whether to allow the right to a dispute to be exercised, provided that certain criteria are met, or to refuse to do so is decisive in the right 'recognition' assessment at the national level. ${ }^{74}$ However, the mere existence of discretionary powers does not automatically preclude the existence of a right ${ }^{75}$ if there are mechanisms and protection of that right. ${ }^{76}$ However, so-called 'unofficial' methods can also be used for protection, i.e. those which are not expressly stipulated in the law but produced by judicial practice. ${ }^{77}$

Thus, taking into account the position of the ECtHR, as well as the existing development of civil procedure law, we consider it possible to provide a more detailed definition of the concept of 'dispute over a right', which is synonymous with the term 'legal dispute' which is used in Art. 124, Para 3 of the Constitution of Ukraine as a criterion for determining court jurisdiction. The latter should be understood as legal deviations arising from legal uncertainty in the subjective rights and obligations of several subjects. It has an internal shape which displays its structure and consists of a subject matter, grounds and content. The subject matter includes subjective rights, freedoms or interests that are recognized in national legislation and are in a state of legal uncertainty, the overcoming of which is decisive for understanding their content, restoration and exersise. The grounds for a dispute include circumstances which give rise to such a condition. In turn, the content of a dispute consists of a cognitive interpretation by a person (the initiator) of the existence of a violation, and the non-recognition or contestation of the opposing party's subjective rights, freedoms or interests, which gives rise to uncertainty and impedes its exercise. The external form of legal dispute expression is always the active action of the dispute initiator, manifested in the request to the opposing party or jurisdictional authority for the restoration of the violated, unrecognized or disputed right, freedom or interest. Legal disputes are always pre-trial and extra-judicial in nature. When it is referred to the court, it is transformed into a claim that is directly subject to the civil case it concerns. ${ }^{78}$

It should be noted that the criterion of a 'dispute over a right' is constantly applied by national courts when deciding whether a case can be tried. The Grand Chamber of the Supreme Court found that, because of this, some cases are not subject to review by the courts, namely: appeal of the Act on the Violation of the Rules on the Electrical Energy Usage does not impose any obligations on the consumer and it is a type of complaint ${ }^{79}$; outlawing actions/inactions of the court (judge or court officials) connected with a case review, as well as claims for the obligation of the court (judge) to perform certain procedural acts because it cannot be dealt

$70 \quad$ Editions Périscope v France App no 11760/85 (ECtHR, 26 March 1993) para 35, Series A no 234-B.

71 W $v$ the United Kingdom App no 9749/82 (ECtHR, 08 July 1987) para 73, Series A no 121-A.

72 Fayed $v$ the United Kingdom App no 17101/90 (ECtHR, 21 September 1994) para 65, Series A no $294-\mathrm{B}$.

73 Roche $v$ The United Kingdom App no 32555/96, para 120, ECHR 2005-X; Masson and Van Zon $v$ the Netherlands App nos 15346/89, 15379/89 (ECtHR, 28 September 1995) para 49, Series A no 327-A.

74 Masson and Van Zon $v$ the Netherlands App no 15346/89, 15379/89 (ECtHR, 28 September 1995) para 50-51, Series A no 327-A; Szücs v Austria App no 20602/92 (ECtHR, 24 November 1997)para 33 Report 1997-VII.

75 Elles and Others $v$ Switzerland App no 12573/06 (ECtHR 16 December 2010) para 16.

76 Boulois $v$ Luxembourg App no 37575/04 para 98 ECHR 2012.

77 Gorou v Greece (No 2) App no 12686/03 (ECtHR, 20 March 2009) para 27.

78 NY Sakara, 'Content and Legal Nature of Legal Dispute' ['Zmist ta pravova pryroda yurydychnoho sporu'] (2017) 46 Uzhgorod National University Scientific journal. Series: Law 63-68.

79 Case no 522/12901/17-ц (Resolution of the Supreme Court of Ukraine, 6 February 2019).. 
with under the rules of any proceedings ${ }^{80}$; the prohibition to issue future orders requiring military personnel to apply for a one-time cash assistance ${ }^{81}$; unlawful notarial action to issue a certificate of acquisition from a public tender ${ }^{82}$; finding a violation of Art. 13 of the ECHR and a fair satisfaction payment ${ }^{83}$, etc.

\subsection{Differentiation of Judicial Procedures}

All procedures, in understanding Art. 6, Para 1 of the ECHR and the practice of the ECtHR, are divided into disputed and undisputed procedures. The first are those that are directly violated in court for the primary resolution of the dispute, as well as those that are the result of an attempt at an out-of-court settlement, that is, when the court performs the socalled 'control functions of the court' by examining the lawfulness of other jurisdictional authorities, such as arbitration.

At the level of the national legal order of Ukraine, the settlement of legal disputes takes place within the limits of legal proceedings (Art. 19, Para 1 of the CPC) as a specific procedure for the consideration and resolution of civil cases. ${ }^{84}$ At the same time, one of the novelties introduced after the new version of the CPC of Ukraine is the introduction of the differentiation of proceedings ${ }^{85}$ in general, and their simplification. The latter has no independent procedural status. It is a consequence of the differentiation of the civil procedure through the exclusion of certain judicial procedures and the establishment of optional procedures for some of them. It cannot be regarded as subsidiary to general proceedings because, although the parties may express their views on its application, the final decision on the type of procedure to be applied is made by the court. ${ }^{86}$ Simplified procedure only deals with certain categories of cases, such as insignificant cases, or cases arising from labour relations. To 'simplify' proceedings (as in some other countries, where there is small claim procedure to review cases where claims are of a small value $)^{87}$ provides for shortened time limits, the absence of separate procedural steps and the possibility of case review without a court hearing with the parties in writing and with optional representation by a lawyer only.

It is embodied in such judicial procedures as proceedings to challenge decisions of arbitration tribunals, challenges of decisions of international commercial tribunals, the recognition and enforcement of decisions of foreign courts, international commercial arbitration in Ukraine, and authorization to enforce arbitration tribunals' decisions (section VIII, IX Civil Procedural Code of Ukraine). Despite the fact- when understanding the ECtHR - that the function of 'judicial control' is implemented only in the first two procedures, nevertheless,

80 Case no 757/43355/16-ц (Resolution of the Supreme Court of Ukraine, 21 November 2018)., Case no 295/7631/17 (Resolution of the Supreme Court of Ukraine, 20 March 2019).

81 Case no 607/15692/19 (Resolution of the Supreme Court of Ukraine, 28 April 2020).

82 Case no 438/610/14-ц (Resolution of the Supreme Court of Ukraine), 7 July 2020).

83 Case no 127/18934/18 (Resolution of the Supreme Court of Ukraine, 22 September 2020).

84 VV Komarov et al, Claim proceeding: monograph ['Pozovne provadzhennia: monohrafiia'] (Law 2011) 7. See also I Izarova, Yu Prytyka, 'Simplified action proceedings of the civil procedure of Ukraine: challenges of the first year of implementation' Problems of Legality No 145, 2019, Pp. 51-67.

85 See D Korol, 'The Value of the Case for the Applicant: A Criterion for the Differentiation of Case Proceedings or of Access to Justice?’ Teise, 2020, 1140, Pp 154-160. Doi: 10.15388/Teise.2020.114.11.

86 NY Sakara, 'Simplified Proceedings as a novelty of Civil Procedure Law' Problems of Civil Law and Procedure: Scientific-practical conference, Kharkiv, 25 May 2018.

87 E Silvestri, 'Small Claims and Procedural Simplification: Evidence from Selected EU Legal System' (2018) 1 Access to Justice in Eastern Europe 6-14; I Izarova, R Flejszar, V Vebraite, 'Access to Justice in Small Claims Procedure: Comparative Study of Civil Procedure in Lithuania, Poland and Ukraine' International Journal of Procedural Law, Volume 9 (2019), No 1, Pp 97-117. 
the ECtHR has investigated the observance of certain guarantees ${ }^{88}$ arising from Art. 6, Para 1 of the ECHR also in the last two types of procedures, i.e. when the existence of a dispute over a right is presumed, although it may be manifestly expressed and not recognized.

In turn, undisputed procedures are generally outside the scope of Art. 6, Para 1 of the ECHR. However, there have been cases where the ECtHR has verified the observance of certain elements of the right to a fair trial in proceedings where no dispute of law has been recognized in the national legal order. As an example, in a case where the proceedings outcome resulted in the restriction of the legal capacity of the individual, a violation of the right to a fair trial was found due to the impossibility of personal explanations being provided ${ }^{89}$ in cases involving the restoration of the legal capacity of a person whose judicial capacity had been restricted or whose legal capacity was impaired, the right of access to a court $^{90}$ and the right to a trial within a reasonable time; ${ }^{91}$ appeals against decisions to admit a person and to provide involuntary psychiatric care - the right to a trial within a reasonable time. ${ }^{92}$ At the same time, the ECtHR declared inadmissible the complaint concerning the violation of the procedural equality of the parties in a paternity case in which the decision had been overturned because of newly discovered circumstances because after its abolition the complainant has not exercised his right to bring an action and the continuation of the proceedings in an undisputed manner was contrary to the requirements of national law. ${ }^{93}$. In addition, the ECtHR discontinued the consideration of the complaint raising the issue of the initiation of Art. 6, Para 1 of the ECHR in the context of the failure to comply with the court order for payment because of the commencement of proceedings to review the legality of the use of budgetary funds, because the complainant did not use adequate and effective remedies. Thus, at the beginning, the complainant had a choice between filing an application for a court order and bringing an action under the general rules of civil procedure. The first way was cheaper and faster than the second, however, it was not sufficient because of the possibility of the authorization of expenditures being denied by the supervisory authorities of the Accounting Chamber. By contrast, the second way open to the complainant would have enabled a court decision to be obtained which was binding on the Accounting Chamber and would have overturned the order of the latter. ${ }^{94}$

The literature suggests that, in indisputable cases, the requirements of the right to a trial such as the independence and impartiality of the court, access to the court, the principle of legal certainty, a reasonable time for trial, etc. must nevertheless be secured. In other words, there are proposals to expand the scope of protection and the applicability of the right to a fair trial ${ }^{95}$. Excluding these proceedings from the scope of Art. 6 of the ECHR would mean that the State is relieved of its obligations to ensure the proper administration of justice in such unacceptable cases. While agreeing in part that it would be appropriate to extend the requirements of the right to a fair trial to certain undisputed procedures, it should be noted that the ECtHR has verified them only through procedures in which a person's condition has been established and has subsequently led to the restriction or the impossibility of rights

88 Selin Asli Oztürk c Turquie App no 39523/03 (ECtHR, 13 Octobre 2009); Ern Makina Sanayi Ve Ticaret AŞ c Turquie App no 70830/01 (ECtHR, 3 May 2007) para 33-34,; Sholokhov v Armenia and Moldova App no 40358/05 (ECtHR, 31 July 2012); K v Italy App no 38805/97 (ECtHR, 20 July 2004); Saccoccia $v$ Austria App no 69917/01 (ECtHR, 18 December 2008).

89 Winterwerp $v$ Netherlands App no 6301/73 (ECtHR, 24 October 1979) para 75, Series A no 33.

90 Stanev $v$ Bulgaria App no 36760/06 (ECtHR, 17 January 2012) para 248; Nataliya Mikhaylenko $v$ Ukraine App no 49069/11(ECtHR, 30 May 2013) para 40.

91 Matter $v$ Slovakia App no 31534/96 (ECtHR 05 July 1999) para 61.

92 Laidin c France (№ 2) App no 39282/98 (ECtHR 7 Janvier 2003) para 91.

93 Alaverdyan v Armenia (dec) App no 4523/04 (ECtHR 24 August 2010) para 36.

94 Beis $v$ Greece App no 22045/93 (ECtHR, 20 March 1997) para 31-36, Reports 1997-II.

95 TA Tsuvina, Trial Right in civil proceedings: monograph (Word 2015) 67-68. 
being exercised, and the ultimate purpose of the application to the court was to determine the extent of the rights and the duties of the person. In this connection, the ECtHR has considered it advisable to provide these guarantees, since the court's activities were as close as possible to resolving disputes which could not be characterized as a dispute of law under the provisions of national law. The same was true of procedures that took place after a prima facie issue had been resolved on the merits through a unilateral, non-confrontational process. At the time the claims were being considered, there was disagreement between the concerned persons. These disagreements were the result of a court decision or arose after a certain period of time, but were directly related to its existence, provided that no other contentious procedure was envisaged at the national level. Thus, there has been a gradual conversion of undisputed procedures into contentious ones, and it is the latter that must be addressed in a fair trial. The ECtHR did not extend the requirements of Art. 6, Para 1 of the ECHR on 'classical' undisputed procedures.

Pursuant to Art. 19, Para 2 of the CPC of Ukraine, legal proceedings are conducted in accordance with the rules action proceedings and the written proceedings. The latter is intended to deal with applications for the recovery of a small claim for which there is no dispute or its existence is unknown to the complainant (Art. 19, part 3, Art. 161 of the CPC of Ukraine), that is, it is 'notionally' uncontested and essentially simplified because it takes place without a court proceeding and without summoning the parties where there would be the possibility of the debtor objecting to the court order. At the same time, the current version of the CPC of Ukraine establishes an alternative to ordinary legal proceedings, since, according to Art. 161, Para 2 of the CPC of Ukraine, a person has the right to apply the requirements set forth in Art. 161, Para 1 of the CPC of Ukraine, in action or summary proceedings of their own choosing. So, they are no longer as mutually exclusive ${ }^{96}$ as they were before. Taking into account the above, as well as the introduction in Ukraine of a 'noproof model' court order, ${ }^{97}$ the guarantees of Art. 6, Para 1, of the ECHR should not extend to summary proceedings.

In civil proceedings, there is another type of procedure, which is a separate procedure, designed to deal with cases concerning the confirmation of the existence or the absence of legal facts that are important for the protection of a person`s rights and interests, or for the creation of conditions to be exercised by a person of personal non-property or property rights, or the confirmation of the existence or the absence of uncontested rights (Art. 19, Para 7, Art. 293 of the Civil Procedural Code of Ukraine). It takes the place of an undisputed production. However, the nature of the law of civil procedure is ambiguous in its evaluation, as some scholars argue that there is a dispute over the right in some cases ${ }^{98}$ or a dispute over the facts. ${ }^{99}$ However, on the basis of the legal positions of the ECtHR referred to above, despite the potential for conflicts, it is hardly possible to accept the 'classical' disputability of these cases on the basis of: (1) the absence of the parties (Art. 42, Para 3 of the CPC of Ukrainian) between which there is a dispute referred to a court for decision; (2) an undisputed procedure for the consideration of the plaintiff's claims addressed to the court and not to other persons; and (3) a direct prohibition to consider disputes about the rights in separate proceedings (Art. 294, Para 6 of the CPC of Ukraine). At the same time, an analysis of the norms of the current CPC of Ukraine makes it possible to classify into two groups the cases dealt with in

96 VV Komarov, Civil procedural legislation in the dynamics and practice of the Supreme Court of Ukraine (Law 2012) 45.

97 VV Komarov et al, Court Administration of Ukraine: Basic State University: Monograph (Law 2016) 605.

98 IV Udaltsova, 'Separate proceedings and problems of recognition of a citizen as having limited legal capacity or incapacity' (Cand of Law thesis, Kharkiv 1999) 4, 10; MI Stefan, Civil Procedure Law of Ukraine: Academic course: Textbook for students (Publishing House Book In Jure 2005) 434-435 ff.

99 VI Tertyshnikov, Civil Process of Ukraine, $4^{\text {th }}$ ed (Publishing house 'Jurait', 2012) 226; DM Chechot, NonContentious Proceeding (Publishing house of Law Faculty of St. Petersburg State University 2005) $448 \mathrm{ff}$. 
separate proceedings. The first group consists of those in which the existence of a dispute over a right results in the denial of the opening of proceedings or the abandonment of an application without consideration and an explanation to the persons concerned that they are entitled to bring an action on a general basis, i.e. that it is 'indeed indisputable. However, these allow for the conversion of an undisputed claim into a disputed claim, which should be considered in the proceedings (the establishment of facts of legal significance, the restoration of rights to lost securities bearer and promissory notes, the transfer of abandoned property to communal property, and the recognition of inheritance as extinct). The second group consists of cases which cannot be converted to contentious cases because of the expressed provision in the law that they can be considered in separate procedure only, that is, they are subject to the established law the 'presumption of indisputability' (the restriction of the legal capacity of a natural person, the recognition of a natural person as lacking legal capacity, ${ }^{100}$ the restoration of the legal capacity of a natural person; the granting of full civil capacity to a juvenile; the recognition of the natural person as missing ${ }^{101}$ or declaring a person dead ${ }^{102}$; adoption; involuntary psychiatric care ${ }^{103}$; compulsory hospitalization in an anti-tuberculosis institution; the disclosure by a bank of information containing bank secrecy concerning legal and natural persons; the issuance and extension of a restraining order). However, since the outcome of the review is determinative of the extent of the rights and duties of the person against whom the decision is made, and this may be objected to by the concerned person as well as by there being no procedure at the national level to influence such subjective rights and duties without altering the relevant court decision in special proceedings, then such cases shall be dealt with in accordance with the requirements of Art. 6, Para 1 of the ECHR. ${ }^{104}$ An exception to this is for adoption cases, as Art. 236 of the Family Code of Ukraine provides for the possibility of filing an action for adoption annulment and abolition.

The 'disputable' and 'indisputable' procedures referred to above, within which the merits of the case are considered, qualify as the main ones, which are opposed by others, such as 'preparatory' ${ }^{105}$ or, as they are still defined in decisions of the ECtHR as 'intermediate' and 'supportive' procedures. The latter, until 2009, were not considered as such to 'resolve' a dispute over civil rights and duties, ${ }^{106}$ however, the ECtHR subsequently changed its position by stating the rule that Art. 6, Para 1, of the ECHR is applicable to such procedures under two conditions. First, the right affected in the main proceedings, that is, when considering the merits of the case and when applying restrictive measures, must be 'civil' in its understanding of the ECHR. Second, the interim measure must affect the right in one way or another and it is a subject of court protection. ${ }^{107}$ Thus, the ECtHR applied Art. 6, Para 1, of the ECHR to the procedures solving the issue of the interim injunction and where the subject matter and the interim measure were more or less the same ${ }^{108}$ their results were decisive for civil rights; ${ }^{109}$ the 'status quo' was kept until the final court decision of the case was adopted, otherwise

100 Case no 88/680/15-ц (Resolution of the Supreme Court of Ukraine, 6 June 2018).

101 Case no 397/712/17-ц (Resolution of the Supreme Court of Ukraine, 14 November 2018).

102 Case no 494/601/16-ц (Resolution of the Supreme Court of Ukraine, 26 September 2018).

103 Case no 523/4937/18 (Resolution of the Supreme Court of Ukraine, 14 January, 2019).

104 Case no 2-2195/05 (Resolution of the Supreme Court of Ukraine, 8 August 2018); Case no 756/552/17 (Resolution of the Supreme Court of Ukraine, 20 June 2018); Case no 607/114/15-ц (Resolution of the Supreme Court of Ukraine, 7 November 2018).

105 R Clayton, H Tomlinson, Fair Trial Rights, $2^{\text {nd }}$ ed (Oxford University Press 2010) 197.

106 Libert c la Belgium (dec) App no 44734/988 (ECtHR, Juillet 2004).

107 Micallef $v$ Malta [GB] App no 17056/06 (ECtHR 15 October 2009) para 83-86.

108 Micallef $v$ Malta (n 109); AKv Liechtenstein App no 38191/12 (ECtHR, 9 July 2015) para 49-55.

109 Udorovich v Italy App no 38532/02 (ECtHR, 18 May 2010) para 37, Pekárny a Cukrárny AS v The Czech Republic App nos 12266/07, 40059/07, 36038/09 and 47155/09 (ECtHR, 12 January 2012) para 66-70. 
the results of the main proceedings would have been nullified, ${ }^{110}$ and an interim decision adopted. ${ }^{111}$ However, the requirements of Art. 6, Para 1 of the ECHR do not apply if the interim measure is only protective in nature, i.e. when it is intended to ensure future court decision, ${ }^{112}$ as well as when procedures are needed for setting aside interim measures. ${ }^{113}$ The ECtHR considers that, in exceptional cases, for example, where the effectiveness of an required intervention depends on the speed of the decision-making process, it may not be possible to respect all procedural guarantees and they should be applied to the extent that is compatible with the nature and purpose of the procedure applied. This concerns primarily the requirement of a public trial. ${ }^{114}$ However, such restrictions may in no case affect the requirement of independence and the impartiality of the court or the judge. ${ }^{115}$ Today in addition to this requirement, ${ }^{116}$ interim measures or procedures have already been subject to violations of the right of access to court ${ }^{117}$ and the enforcement of the court decision by the ECHR, otherwise the right of access to the main court is violated ${ }^{118}$.

In procedural law science, it is suggested that interim measures should be understood as limitations, prohibitions and duties imposed by the court for a specific period of time to give rise to special material obligations, the legal regime governing the security and the guarantee of the execution of judicial acts, the cessation of unlawful activities, the prevention of damage and the obtaining of necessary evidence by the court. These include: the provision of evidence (Arts. 116-119 of the CPC of Ukraine), the security and prepayment of court costs (Arts. 135 of the CPC of Ukraine), the provisional seizure of evidence for court examination (Art. 146 of the CPC of Ukraine), and claim enforcement and counter enforcement (Arts. 149-159 of the CPC of Ukraine). At the same time, it seems that, according to the position of the ECtHR, the requirements of Art. 6, Para 1 of the ECHR should be observed only when the enforcement of a claim, by prohibiting certain actions, establishes a duty to perform certain acts: prohibiting other persons acting in relation to the subject matter of the dispute, from making payments, transferring property to the respondent or performing other duties towards it; halting the sale of seized property, if an action for the recognition of ownership of the property and for the removal of the arrest is filed; and so on. We believe that the other means to enforce the claim listed in Art. 150, Para 1 of the CPC of Ukraine are only protective in nature and intend to ensure the continued enforcement of the court decision, that is, the provisions of Art. 6, Para 1 of the ECHR do not expand to their application.

Although Art. 6, Para 1 of the ECHR does not provide for the right of appeal and cassation, the ECtHR relies on States that establish a system of courts for the review of judicial decisions with requirements to ensure that the fundamental guarantees enshrined in this note are provided within their jurisdiction. ${ }^{119}$ However, the manner in which the right to a fair trial is applied in the proceedings before such courts depends on their specificities, taking into account the continuity of these proceedings in national proceedings and the role

110 Kübler v Germany App no 32715/06 (ECtHR, 13 January 2011) para 48; Sharxhi and Others v Albania App no 10613/16 (ECtHR 11 January 2018 para 94).

111 Mercieca and Others $v$ Malta App no 21974/07 (ECtHR, 14 June 2011) para 35.

112 Štokalo and Others $v$ Croatia (dec) App no 22632/07 (ECtHR, 3 May 2011); Imobilije Marketind DOO and Debelić v Croatia (dec) App no 23060/07 (ECtHR, 3 May 2011).

113 Fedotova $v$ Russia (dec) App no 73225/01 (ECtHR, 1 April 2004).

114 Udorovich $v$ Italy App no 38532/02 (ECtHR, 18 May 2010) para 48-51.

115 Micallef $v$ Malta [GB] App no 17056/06 (ECtHR, 15 October 2009) para 86;

116 Micallef $v$ Malta (n 109) para 103; K v Liechtenstein (n 110) para 84.

117 Mercieca and Others $v$ Malta (n 113) para 50-51; Pekárny a Cukrárny AS v The Czech Republic (n 111) para 76-79.

118 Kübler v Germany (112) para 64-66; Sharxhi and Others $v$ Albania (n 112) para 95-97.

119 Levages Prestations Service v France App no 21920/93 (ECtHR 23 October 1996) para 44, Reports 1996-V. 
of the higher courts therein. ${ }^{120}$ In other words, the ECtHR emphasizes the need to respect the right to a fair trial, not only in the first instance, but also in the review of judgements by the courts of appeal and cassation. However, appealed court decisions should relate to subjective rights, freedoms or interests that are subject to judicial protection, and should not be limited to procedural matters (the referral of cases to the courts, ${ }^{121}$ the enforcement of a claim abolition, ${ }^{122}$ etc.). At the same time, the ECtHR recognizes as lawful, and in the interest of the proper administration of justice, the imposition of certain additional restrictions, both in the exercise of the right of access to a court (ratione valoris, ${ }^{123}$ the period of the resourse to the court, ${ }^{124}$ follow-ups to complaints procedures ${ }^{125}$ etc.), and directly before such courts, taking into account the extent to which the case has been tried in the lower courts, whether or not there are issues related to the fairness of the proceedings before the lower courts, as well as the nature of the court powers under consideration. ${ }^{126}$ That is to say, the ECtHR provides a certain degree of 'restrictive' interpretation of individual provisions of Art. 6, Para 1, of the ECHR on procedures for a review of court decisions. This position also applies to a review of newly discovered circumstances. ${ }^{127}$ At the same time, the established practice of the ECtHR is that complaints about exceptional circumstances that require the reinstatement of closed proceedings do not, as a rule, include the resolution of a dispute over 'civil nature rights and duties'. So, Art. 6, Para 1 of the ECHR is therefore considered inapplicable for review procedures. However, if an extraordinary complaint concerns or results in a retrial, the rule will apply to 'retrial' proceedings, as a general rule ${ }^{128}$.

It should be noted separately that the ECtHR as well applies Art. 6, Para 1 of the ECHR to procedures that take place after the adoption of the court, thus distinguishing between jurisdictional activities and the execution of the judgement. Thus, as already mentioned, the latter is considered as an integral part of the 'trial'. However, regardless of the application of Art. 6, Para 1 of the ECHR to the initial review, an executive document that establishes civil rights and duties need not necessarily be issued in the dispute that is the subject to this provision. ${ }^{129}$

\subsection{Civil nature of the rights and duties as the protection objects}

'Civil' nature is the most controversial and, we might say, the least defined concept in ECtHR practice. At the beginning, despite the autonomous interpretation of the categories used in the text of the ECHR, civil rights and duties were interpreted exclusively as being covered by the concept of 'private rights', that is the association of civil law with private law. ${ }^{130}$ Since then, the ECtHR has changed its approach by adopting an evolutionary approach, on the basis that the legal qualification of rights and duties depends not so much on their characterization by domestic law as on their material content, and its implications. ${ }^{131}$ For the application of Art. 6, Para 1 of the ECHR it is necessary that the claim is for a property item and it is based

120 Tolstoy Miloslavsky v United Kingdom App no 18139/91 (ECtHR, 30 July 1995) para 59, Series A no 316-B.

121 Kolomiyets v Russia App no 76835/01 (ECtHR, 22 February 2007) para 34.

122 Fedotova $v$ Russia ((n 115).

123 Brualla Gómez de la Torre v Spain App no 26737/95 (ECtHR, 19 December 1997) para 36, Reports 1997-VIII.

124 Pérez de Rada Cavanilles v Spain App no 28090/95 (ECtHR, 28 October 1998) para 45, Reports 1998-VIII.

125 Walchli $v$ France App no 35787/03 (ECtHR, 26 July 2007) para 29-37.

126 Zubac v Croatia App no 40160/12 (ECtHR, 5 April 2018) para 84.

127 Pravednaya $v$ Russia App no 69529/01 (ECtHR, 18 November 2004) para 27-34.

128 Bochan v Ukraine (no 2) App no 22251/08 para 44, 46, ECtHR 2015.

129 Buj v Croatia App no 24661/02 (ECtHR, 1 June 2006) para 19.

130 TA Tsuvina, Trial Right in civil proceedings: monograph [Pravo na sud u tsyvilnomu sudochynstvi: monohrafiia] (Slovo 2015) 60.

131 König v Germany App no 6236/73 (ECtHR, 28 June 1978) para 89, Series A no 27. 
on an infringement of property rights, despite the existence of a dispute and the competence of the administrative authority to deal with it. ${ }^{132}$ At the same time, the monetary nature of a claim is important but not decisive. ${ }^{133}$ For example, an action for compensation for the denial of housing and granting refugee status does not change the situation that, in fact, the person contests the legality of the decision. ${ }^{134}$ Moreover, this rule is also used in the consideration of non-property claims. ${ }^{135}$ To qualify the claim as 'civil', the elements of private law should prevail over the elements of public law. ${ }^{136}$ However, the practice of the ECtHR has not developed universal criteria that are taken into account.

If, in the national legal order, private disputes are defined as civil disputes, the provisions of the domestic law are unconditional for the EctHR, and they are subject to the requirements of Art. 6, Para 1 of the ECHR accordingly. ${ }^{137}$ However, as already noted, this rule also applies to other cases in which the rights of public law are decided, but whose effects are decisive for the rights and obligations of private persons. ${ }^{138}$ Thus, the ECtHR extended the regime of disputes concerningrights and obligations of a 'civil nature' to disputes that were related to family; ${ }^{139}$ to residence; ${ }^{140}$ to land relations; ${ }^{141}$ to social security relations; ${ }^{142}$ to the privatization of State property ${ }^{143}$ to the licensing and the authorization of certain activities; ${ }^{144}$ to relations with securities; ${ }^{145}$ to bankruptcy; ${ }^{146}$ to the termination of the activities of a legal person, including a bank; $;^{147}$ to access information if this is necessary for the reporter to carry out duties; ${ }^{148}$ to appeals against decisions of the authorities; ${ }^{149}$ to compensation for damage caused by unlawful

132 Procola v Luxemburg App no 14570/89 (ECtHR, 28 September 1995) para 38-39, Series A no 326.

133 Pierre-Bloch v France App no 24194/94 (ECtHR, 21 October 1997) para 51, Reports 1997-VI.

134 Panjeheighalehei v Denmark (dec) App no 11230/07 (ECtHR, 13 October 2009).

135 Taşkin and Others $v$ Turkey App no 46117/99, (ECtHR, 10 November 2004) para 133, ECHR 2004-X.

136 Deumeland v Germany App no 9384/81 (ECtHR, 29 May 1986) para 59-74, Series A no 100.

137 Airey $v$ Ireland App no 6289/73 (ECtHR, 09 October 1979) para 21, Series A no 32.

138 Ringeisen v Austria App no 2614/65 (ECtHR, 19 March 1970) para 94, Series A no 13.

139 W $v$ the United Kingdom App no 9749/82 (ECtHR, 08 July 1987) para 72-79, Series A no 121; Olsson $v$ Sweden (№ 1) App no 10465/83 (ECtHR, 24 March 1988) para 88-90, Series A no 130; Olsson $v$ Sweden (№ 2) App no 13441/87 (ECtHR, 27 November 1992) para 95-107, Series A no 250; Keegan v Ireland App no 16969/90, (ECtHR, 26 May 1994) para 57, Series A no 290; Johansen v Norway App no 17383/90 (ECtHR, 7 August 1996) para 87-88, ECHR 1996-III, Görgülü v Germanu Appno 74969/01 (ECtHR, 26 February 2004) para 56-50; Bianchi v Switzerland App no 7548/04 (ECtHR, 22 June 2006) 101-115.

140 Gillow $v$ the United Kingdom App no 9063/80 (ECtHR, 24 November 1986) para 68-75, Series A no 109.

141 Allan Jacobsson $v$ Sweden (№ 1) App no 10842/84 (ECtHR, 25 October 1989) para 72-74, Series A no 163; Hentrich $v$ France App no 13616/88 (ECtHR, 22 September 1994) para 52, Series A no 296-A; Aldo and Jean-Baptiste Zanatta $v$ France App no 38042/97 (ECtHR, 28 March 2000) para 22-26.

142 Felbrugge $v$ Netherlands App no 8562/79 (ECtHR, 29 May 1986) para 29-40, Series A no 99; Salesi $v$ Italy App no 13023/87 (ECtHR, 26 February 1993) para 17-19, Series A no 257-E; Schouten and Meldrum $v$ Netherlands App nos 19005/91, 19006/91 (ECtHR, 09 December 1994) para 47-60, Series A no 304; Mennitto $v$ Italy [GC] App no 33804/96, para 21-28, ECHR 2000-X.

143 Industrial Financial Consortium Investment Metallurgical Union v Ukraine App no 10640/05 (ECtHR, 26 June 2018) para 113-115.

144 Sporrong and Lönnroth $v$ Sweden App nos 7151/75, 7152/75 (ECtHR, 23 September 1982) para 72-79, Series A no 121; Benthem $v$ the Netherlands App no 8848/80 (ECtHR, 23 October 1985) para 36, Series A no 97; Tre Traktörer Aktiebolag $v$ Sweden App no 10873/84 (ECtHR, 7 July 1989) para 41-43, Series A no 159; Pudas $v$ Sweden App no 10426/83 (ECtHR, 27 October 1987) para 36-38, Series A no 125-A.

145 Bakiyevets $v$ Russia App no 22892/03 (ECtHR, 15 June 2006) para 32-40.

146 Ceteroni v Italy App nos 22461/93, 22465/93 (ECtHR, 15 November 1996) ECHR 1996-V; Bassani v Italy App no 47778/99 (ECtHR, 11 December 2003) para 13-14.

147 Capital Bank AD v Bulgaria App no 4942/99 (ECtHR, 24 November 2005) para 88.

148 Loiseau c France App no $46809 / 99$ (ECtHR, 28 Septembre 2004) para14-16; Kenedi v Hungary App no 31475/05 (ECtHR, 26 May 2009) para 33-34; Shapovalov v Ukraine App no 45835/05 (ECtHR, 31 July 2012) para 42-50; Rosiianu v Romania App no 27329/06 (ECtHR, 24 June 2014) para 35. Alatulkkila and Others $v$ Finland App no 33538/96 (ECtHR, 28 July 2005) para 49-50. 
acts or inaction of the police, ${ }^{150}$ to the illegal detention ${ }^{151}$ or the inaction of a public authority, ${ }^{152}$ etc. In addition, this provision applies to constitutional proceedings if they have a significant impact on the outcome of a civil rights and duties dispute, ${ }^{153}$ as well as to criminal proceedings in which a civil action is brought, ${ }^{154}$ except those cases when the presentation of the latter is made purely for the purpose of personal vengeance, ${ }^{155}$ or as punishment. ${ }^{156}$

The evolution of the position of the ECtHR in extending Art. 6, Para 1 of the ECHR to cases involving a public servant is noteworthy. Thus, at the beginning, in order to exclude disputes concerning recruitment, service and dismissal from the scope of its application of Art. 6, Para 1 of the ECHR, the presumption was applied, except for those cases where the claims were 'economic' in nature, i.e. payment of wages, ${ }^{157}$ retirement ${ }^{158}$ or were in essence 'economic' (recovery of wage difference, compensation for late execution of judgment) ${ }^{159}$ if the relevant decision of the public authority was not contested. ${ }^{160}$ The 'functional' criterion, according to which the nature of the powers and duties performed by the civil servants has to be taken into account, was developed. The ECtHR was of the view that Art. 6, Para 1 of the ECHR should exclude only disputes between public officials whose duties include specific activities, given that they perform the functions of a public authority for the protection of the interests of the State, for example, where disputes are between military and police personnel. ${ }^{161}$ In 2007 , the approach changed and the presumption began to apply to all fair trial guarantees. At the same time, it may be derogated under a number of conditions. First, the State must expressly exclude from its national legislation access to a court for certain public offices or categories of public officials. Second, such exceptions must be subject to objective considerations of public interest. This obliges the State to justify that the subject matter of the dispute in question relates to the exercising of governmental authority otherwise the special relationship between a public official and the State can be called into issue. ${ }^{162}$ On the basis of these criteria, the ECtHR applied Art. 6, Para 1 of the ECHR in cases involving the employment of embassy staff, ${ }^{163}$ police officers, ${ }^{164}$ judges, ${ }^{165}$ and parliamentary assistants ${ }^{166}$ etc.

However, despite the property nature of tax disputes and the direct impact of their outcome on the financial situation of a party, they are not used at the time of their adjudication under Art. 6, Para 1 of the ECHR, except for disputes concerning the recovery of excessive taxes paid. ${ }^{167}$ The ECtHR takes the position that tax matters form a part of the main package of

150 Osman $v$ the United Kingdom App no 23452/94 (ECtHR, 28 October 1998) para 138-140, Reports 1998-VIII.

151 Georgiadis $v$ Greece App no 21522/93 (ECtHR, 29 May 1997) para 35, Report 1997-III.

$152 X v$ France App no 18020/91 (ECtHR, 31 March 1992) para 28-30, Series A no 234-C.

153 Ruiz-Mateos v Spain App no 12952/87 (ECtHR, 23 June 1993) para 59, Series A no 262; Kübler v Germany App no 32715/06 ECtHR 2011, para 44-48.

154 Perez v France [GC] App no 47287/99 (ECtHR,12 February 2004) para 70-71, ECHR 2004-I.

155 Mihova $v$ Italy (dec) App no 25000/07 (ECtHR, 30 March 2010).

156 Sigalas $v$ Greece (App no 19754/02, ECtHR 22 September 2005) para 29-30.

157 De Santa v Italy App no 25574/94 (ECtHR, 2 September 1997) para 18, Reports 1997-V.

158 Massa $v$ Italy App no 14399/88 (ECtHR, 24 August 1993) para 26, Series A no 265-B.

159 Nicodemo v Italy App no 25839/94 (ECtHR, 2 September 1997) para 18, Reports 1997-V.

160 Benkessiouer v France App no 26106/95 (ECtHR, 24 August 1998) para 30, Reports 1998-V.

161 Pellegrin v France [GC] App no 28541/95 (ECtHR, 8 December 1999) para 64-66, ECHR 1999-VIII.

162 Vilho Eskelinen and Others v Finland [GC] App no 63235/00 (ECtHR, 19 April 2007) para 62, ECHR $2007-$ II.

163 Cudak v Lithuania [GC] App no 15869/02 (ECtHR, 23 March 2010) para 44-47.

164 Šikić v Croatia App no 9143/08 (ECtHR, 5 July 2010) para 18-20.

165 Oleksandr Volkov v Ukraine App no 21722/11 (ECtHR, 9 January 2013) para 87-91; Baka v Hungary [GC] App no 20261/12 (ECtHR, 23 June 2016) para 100-106.

166 Savino and Others $v$ Italy App nos 17214/05, 42113/04, 20329/05 (ECtHR, 24 April 2009) para 70-79.

167 Editions Périscope v France App no 11760/85 (ECtHR, 26 March 1992) para 40, Series A no 234-B; National \& Provincial Building Society and Others $v$ the United Kingdom App nos 21319/93, 21449/93, 21675/93 (ECtHR, 23 October 1997) para 94-99, ECHR 1997-II. 
public authorities' prerogatives. The relationship between the taxpayer and the tax authority is essentially public. Bearing in mind that the ECHR and its Protocols must be interpreted in the light of their totality, the ECtHR notes that Art. 1 of Protocol 1, which deals with the protection of the ownership, retains the right of the State to enact the laws it deems necessary, to ensure the payment of taxes. ${ }^{168}$ In addition, elements of public law prevail in customs cases, ${ }^{169}$ political cases, ${ }^{170}$ selective relations, ${ }^{171}$ immigration relations, including the granting of asylum ${ }^{172}$ or deportation, ${ }^{173}$ extradition, ${ }^{174}$ citizenship, ${ }^{175}$ the performance of military duty, ${ }^{176}$ education, ${ }^{177}$ access to information and reporting related to trials, ${ }^{178}$ changing personal data, ${ }^{179}$ tendering and public contracts, ${ }^{180}$ disputes between State and local authorities, ${ }^{181}$ etc.

Following from the above, civil proceedings in Ukraine deal with cases arising from civil, land, labour, family, housing and other legal relations (Art. 19, Para 1 of the CPC of Ukraine). It is undeniable that civil proceedings must respect the guarantees of a fair trial. This rule may be derogated only in cases of orders and certain special proceedings, as discussed above, since the latter are indisputable and therefore not covered by Art. 6, Para 1 of the ECHR.

\section{CONCLUSIONS}

We believe that it is appropriate to conclude that the right to a fair trial is a substantive right, manifested in a combination of its fundamental and positive natures; its national and supranational regulation; and the simultaneous embodiment of the elements of both subjective law and axiom, as well as the elements of procedural and substantive law. Even though Ukraine has assumed the obligation to guarantee rights in ratifying the ECHR, the substance of this right is only partially incorporated into the national legal system, since the latter is not yet recognized as a separate protection object.

The scope of applicability of this right is not universal and it is determined by the legally binding subjects and procedures to which the guarantees of Art. 6, Para 1 of the ECHR apply.

168 Ferrazzini v Italy [GC] App no 44759/98 (ECtHR, 12 July 2001) para 29, ECHR 2001-VII.

169 Emesa Sugar v the Netherlands (dec) App no 62023/00 (ECtHR, 13 January 2005).

170 Refah Partisi (the Welfare Party) and Others $v$ Turkey (dec) App no 41340/98-41344/98 (ECtHR, 3 October 2000); Herri Batasuna et Batasuna c Espagne (dec) App nos 25803/04, 25817/04 (ECtHR, 11 Décembre 2007).

171 Pierre-Bloch v France App no 24194/94 (ECtHR, 21 October 1997) para 50; Ždanoka v Latvia (dec) App no 58278/00 (ECtHR, 6 March 2003); Paksas v Lithuania [GC] App no 34932/04 (ECtHR, 1 June 2011) para 65-67; Cherepkov v Russia App no 51501/99 (ECtHR, 29 January 2000).

172 Panjeheighalehei v Denmark (dec, App no 11230/07 (ECtHR, 13 October 2009).

173 Maaouia v France [GC] App no 39652/98 5 October 2010, para 38, ECHR-X.

174 Peñafiel Salgado $v$ Spain (dec) App no 65964/01 (ECtHR, 16 April 2002); Mamatkulov and Askarov $v$ Turkey [GC] App nos 46827/99, 46951/99 (ECtHR, 4 February 2005) para 81-83; Schuchter c Italie (déc) App no 68476/10 (ECtHR, 11 octobre 2011).

175 Sergey Smirnov v Russia (dec) App no 14085/04 (ECtHR, 6 July 2006).

176 Nicolussi v Austria (dec) App no 11734/85 (ECtHR, 8 May 1987) DR no 52.

177 Simpson $v$ the United Kingdom (dec) App no 14688/89 (ECtHR, 4 December 1989) DR no 64.

178 G Hodgson D Woolf Productions Ltd and National Union of Journalists $v$ the United Kingdom and Channel Four Television Co Ltd $v$ the United Kingdom (dec) App nos 11553/85, 11658/85 (ECtHR, 9 March 1987) DR no 51; MacKay and BBC Scotland $v$ the United Kingdom App no 10734/05 (ECtHR, 7 December 2010) para 22; Truckenbrodt v Germany (dec) App no 49849/08 (ECtHR, 30 June 2015).

179 Dalea c France (dec) App no 964/07 (ECtHR, 2 Fvrier 2010).

180 ITC LTD v Malta (dec) App no 2629/06 (ECtHR, 11 December 2007).

181 Hatzitakis et les Mairies de Thermaikos et Mikra c Grece (dec) App nos 48391/99, 48392/99 (ECtHR, 18 Mai 2000). 
These are not only 'courts', but also in some cases, other jurisdictional bodies authorized to provide administrative and alternative forms of protection, as well as authorities and persons which carry out the implementation of decisions. In turn, procedures based on whether or not there is a dispute over a right are divided into 'disputable' procedures within which guarantees of a fair trial right must always be respected; and 'conditionally disputable' procedures i.e. those which are, as a rule, intended for the review of indisputable issues, but which can presumably transform into 'disputable' procedure. This implies a need to reestablish the requirements of Art. 6, Para 1 of the ECHR for consideration at a later stage when there is a need to verify disputability or to settle the dispute between the persons concerned, which may be of a latent nature. There are also 'indisputable' procedures of which the main purpose is to resolve purely procedural matters; the procedure for review is not regulated by the ECHR and is subject to the supervision of the ECtHR. As for a general rule, these procedural matters always belong to a disputable or 'conditionally' disputable procedure, however, are autonomous in nature, that is, in most cases they arise on the condition that the parties show initiative, if they consider this initiative necessary. Their integration may be different, that is, they either precede the trial or take place simultaneously with it, pursuing both their own objectives and, indirectly, the common objectives of the trial. Within the framework of such procedures, the protection of 'civil' rights and freedoms must be carried out and must fully correspond to the subject area of civil procedure in Ukraine.

\section{REFERENCES}

Sakara NY, 'Impact of the human rights fundamentalization on the development of the fair trial right' ['Vplyv fundamentalizatsii prav liudyny na stanovlennia prava na spravedlyvyi sudovyi rozghliad'] Rule of law issues (2017) 13851.

Lautenbach G, The Concept of the Rule of Law and the European Court of Human Rights (OUP 2013) 174;

Thurman WA, 'The Role of Substantive Law and Procedure in the Legal Process' (1932) XLV (4) Harward Law Review 639, 643-644.

Yukov MK, 'Civil Procedural Law. Issues of development and protection of citizens' rights' ['Sviazy norm hrazhdanskoho y hrazhdanskoho protsessualnoho prava. Voprosi razvytyia i zashchyti prav hrazhdan: mezhvuz. temat. sb.'] (RE Gukasian ed, Kaliningradskiy Gos. Universitet 1977) 66-75.

Temirbekov JR, 'Some features of understanding the rule of law in US constitutional theory' ['Nekotorye osobennosti ponymaniya verkhovenstva prava v konstitutsyonnoi teorii'] (2015) 1 (66) Law and State 53-54.

Sviridenko OM, 'Substantive legal relations as an integral part of the insolvency (bankruptcy) concept' ['Substantyvnye pravootnoshenyia kak sostavnaia chast kontseptsyy nesostoiatelnosty (bankrotstva)'] (2010) 11 Modern law 76-77.

Savchenko SA, 'Interaction Process of norms and principles of international and national law' ['Protsess vzaymodeistvyia norm y pryntsypov mezhdunarodnoho y natsyonalnoho prava'] (2010) 3 Gazette of the Moscow University of the Ministry of Internal Affairs of Russia 154.

Sahnova TV, 'Right to Judicial Protection as a Substantive Procedural Law: The Effect of Globalization' ['Pravo na sudebnuiu zashchytu kak substantyvnoe protsessualnoe pravo: effekt hlobalyzatsyy'] (2014)3 The Bulletin of Civil Procedure 11-25.

European Commission For Democracy through Law (Venice Commission), Report on the Rule of Law. Venice, 25-26 March 2011 <http://www.venice.coe.int/webforms/documents/default. aspx?pdffile=CDL-AD(2011)003rev-rus > accessed 6 February 2021.

Sakara NY, 'Impact of the human rights fundamentalization on the development of the fair trial right' ['Vplyv fundamentalizatsii prav liudyny na stanovlennia prava na spravedlyvyi sudovyi rozghliad'] (2017) 138 Problemy Zakonnosti 43-54. 
Prokopenko OB, The fair trial right: conceptual analysis and implementation practice [Pravo na spravedlyvyi sud: kontseptualnyi analiz i praktyka realizatsii] (Publishing House FINN 2011) 63.

SakhnovaTV,'Procedure of the CivilisticProcess:Future Methodology'['Protsedurnost tsyvylystycheskoho protsessa: metodolohyia budushcheho'] (2012) 1 Bulletin of the Civil Process 13-14.

Komarov VV et al, Civic Process Course: Textbook [Kurs tsyvilnoho protsesu: pidruchnyk] (Law 2011) 17.

Tsuvina TA, 'Peculiarities of the calculation of the reasonable period of civil proceedings in the context of the jurisprudence of the European Court of Human Rights' ['Osoblyvosti obchyslennia rozumnoho stroku sudovoho rozghliadu tsyvilnykh sprav u konteksti praktyky Yevropeiskoho sudu z prav liudyny'] (2015) 130 Problems of Legality 98.

Sakhnova TV, 'Civic Process Course: Theoretical Beginnings and Basic Institutions' ['Kurs hrazhdanskoho protsessa: teoretycheskye nachala y osnovnbe institutu'] (Wolters Kluwer 2008) 14.

Marmazov V, Pushkar P,'Is there a right to a fair arbitration guaranteed by the European Convention on Human Rights?' ['Chy isnuie pravo na spravedlyvyi arbitrazhnyi rozghliad sprav, harantovanyi yevropeiskoiu konventsiieiu z prav liudyny'] (2011) 1 Law of Ukraine 37-49.

Turkanova V, 'Open Enforcement: New Approach of Ukraine in Access to Justice' (2019) 2 Access to Justice in Eastern Europe.

Sakara NY, 'Content and Legal Nature of Legal Dispute' ['Zmist ta pravova pryroda yurydychnoho sporu'] (2017) 46 Uzhgorod National University Scientific journal. Series: Law 63-68.

Komarov W et al, Claim proceeding: monograph ['Pozovne provadzhennia: monohrafiia'] (Law 2011) 7

Izarova I , Prytyka Yu, 'Simplified action proceedings of the civil procedure of Ukraine: challenges of the first year of implementation' Problems of Legality ['Sproshchene pozovne provadzhennia tsyvilnoho sudochynstva Ukrainy: vyklyky pershoho roku zastosuvannia $v$ sudovii praktytsi'], No 145, 2019, Pp. 51-67.

Korol D, 'The Value of the Case for the Applicant: A Criterion for the Differentiation of Case Proceedings or of Access to Justice?' Teisè, 2020, 1140, Pp. 154-160. Doi: 10.15388/Teise.2020.114.11.

Sakara NY, 'Simplified Proceedings as a novelty of Civil Procedure Law' ['Sproshchene pozovne provadzhennia yak novela tsyvilnoho protsesualnoho prava'] Problems of Civil Law and Procedure: Scientific-practical conference, Kharkiv, 25 May 2018.

Silvestri E, 'Small Claims and Procedural Simplification: Evidence from Selected EU Legal System' (2018) 1 Access to Justice in Eastern Europe 6-14

Izarova I, Flejszar R, Vebraite V, 'Access to Justice in Small Claims Procedure: Comparative Study of Civil Procedure in Lithuania, Poland and Ukraine' International Journal of Procedural Law, Volume 9 (2019), No 1, Pp. 97-117.

Tsuvina TA, Trial Right in civil proceedings: monograph ['Pravo na sud $\mathrm{u}$ tsyvilnomu sudochynstvi: monohrafiia'] (Word 2015) 67-68.

Komarov VV, Civil procedural legislation in the dynamics and practice of the Supreme Court of Ukraine [Tsyvilne protsesualne zakonodavstvo u dynamitsi rozvytku ta praktytsi Verkhovnoho Sudu Ukrainy] (Law 2012) 45.

Komarov VV et al, Court Administration of Ukraine: Basic State University: Monograph ['Tsyvilne sudochynstvo Ukrainy: osnovni zasady ta instytuty: monohrafiia'] (Law 2016) 605.

Udaltsova IV, 'Separate proceedings and problems of recognition of a citizen as having limited legal capacity or incapacity' ['Okreme provadzhennia ta problemy vyznannia hromadianyna obmezheno diiezdatnym chy nediiezdatnym'] (Cand of Law thesis, Kharkiv 1999) 4, 10

Stefan MI, Civil Procedure Law of Ukraine: Academic course: Textbook for students (Publishing House Book In Jure 2005) 434-435 ff.

Tertyshnikov VI, Civil Process of Ukraine [Tsyvilnyi protses Ukrainy], $4^{\text {th }}$ ed(Publishing house 'Jurait', 2012) 226; DM Chechot, Non-Contentious Proceeding ['Neyskovye proyzvodstva'] (Publishing house of Law Faculty of St. Petersburg State University 2005) $448 \mathrm{ff}$.

Clayton R, Tomlinson H, Fair Trial Rights, $2^{\text {nd }}$ ed (Oxford University Press 2010) 197. 